\title{
Blue Native PAGE and Antibody Gel Shift to Assess Bak and Bax Conformation Change and Oligomerization
}

\author{
Grant Dewson ${ }^{1}$ \\ Cell Signalling and Cell Death Division, Walter and Eliza Hall Institute of Medical Research, Parkville, \\ Melbourne, Victoria 3052, Australia; Department of Medical Biology, The University of Melbourne, Melbourne, \\ Victoria 3010, Australia
}

Blue native PAGE (BN-PAGE) uses Coomassie dye rather than denaturing SDS to provide a negative charge to proteins for electrophoresis. As such, it is a useful assay for investigating native supramolecular membrane complexes without the need for cross-linking. As Bak and Bax oligomers form in the mitochondrial outer membrane, and they can be efficiently monitored by BN-PAGE. Furthermore, BN-PAGE performed in conjunction with gel-shift using conformation-specific antibodies can provide additional information regarding the activation state of Bak or Bax in specific membrane complexes.

MATERIALS

It is essential that you consult the appropriate Material Safety Data Sheets and your institution's Environmental Health and Safety Office for proper handling of equipment and hazardous materials used in this protocol.

RECIPES: Please see the end of this protocol for recipes indicated by $<R>$. Additional recipes can be found online at http://cshprotocols.cshlp.org/site/recipes.

Reagents

Acetic acid

Anode buffer (25 mm imidazole/HCl, pH 7.0)

Antibodies

Antibodies for gel-shift, conformation-specific (for Bax and/or Bak, e.g., anti-Bax 6A7 or anti-Bak 23-38)

Irrelevant control antibody (of the same isotype)

Positive control antibody (for the inactive, active, and oligomerized forms of Bak or Bax)

Blue native PAGE (BN-PAGE) loading buffer $(10 \times)<\mathrm{R}>$

Cathode buffer I $(10 \times)<\mathrm{R}>$

Cathode buffer II $(10 \times)<\mathrm{R}>$

Coomassie stain $<\mathrm{R}>$

Digitonin

Immediately before use, prepare a fresh solution of $10 \%(\mathrm{w} / \mathrm{V})$ digitonin in $\mathrm{H}_{2} \mathrm{O}$ and boil to dissolve. Alternatively, resuspend in DMSO for long-term storage.

\footnotetext{
${ }^{1}$ Correspondence: dewson@wehi.edu.au

(c) 2015 Cold Spring Harbor Laboratory Press

Cite this protocol as Cold Spring Harb Protoc; doi:10.1101/pdb.prot086488
} 
G. Dewson

\section{Equipment}

Centrifuge (benchtop) at $4^{\circ} \mathrm{C}$

Centrifuge tubes

Hemocytometer

Polyvinyl difluoride (PVDF) membrane

SDS-PAGE apparatus (preferably an old kit as it will be stained with Coomassie dye!)

Water bath at $65^{\circ} \mathrm{C}$

Western transfer apparatus

METHOD

As needed, a reducing agent such as dithiothreitol (DTT) may be added at a concentration of 2-10 mu throughout sample preparation (Steps 3-8); see Discussion.

\section{Inducing Apoptosis and Permeabilizing Cells}

1. Treat cells with an apoptotic stimulus as required.

2. Harvest the cells by centrifugation at $2500 \mathrm{~g}$ for $5 \mathrm{~min}$. Wash once in $1 \mathrm{~mL}$ of ice-cold $1 \times \mathrm{PBS}$. Perform a cell count using a hemocytometer.

3. Centrifuge the cells at $2500 \mathrm{~g}$ for $5 \mathrm{~min}$ and discard the supernatant. Gently resuspend the cell pellet in permeabilization buffer supplemented with $0.025 \%$ digitonin and protease inhibitors at $1 \times 10^{7}$ cells per $\mathrm{mL}$.

Although not absolutely necessary, this permeabilization step removes cytosolic proteins and therefore reduces background during immunoblotting. It also allows for the addition of conformation-specific antibodies for gel-shift assay.

4. Pellet the membranes by centrifugation at $13,000 \mathrm{~g}$ for $5 \mathrm{~min}$. Discard the supernatant (cytosolic fraction).

5. If performing gel-shift, proceed to Step 6. Otherwise, proceed directly to Step 8. 


\section{Antibody Gel-Shift and BN-PAGE}

6. Resuspend the membranes in permeabilization buffer (with protease inhibitors but without digitonin). Add 1-2 $\mu \mathrm{g}$ of conformation-specific anti-Bak or anti-Bax antibody or a control antibody to each sample. Incubate on ice for $30 \mathrm{~min}$.

Antibody concentration and time of incubation should be determined empirically.

7. Centrifuge the samples at $13,000 \mathrm{~g}$ for $5 \mathrm{~min}$ to pellet membranes. Discard the supernatant.

8. Resuspend the membranes in solubilization buffer with $1 \%$ digitonin by pipetting rapidly with a P200 pipette. Incubate for $30 \mathrm{~min}$ on ice.

We routinely resuspend MEF at $1 \times 10^{7}$ cells $/ \mathrm{mL}$. This step is critical for the efficient solubilization of the membrane complexes and their resolution on BN-PAGE.

9. Centrifuge the samples at $13,000 \mathrm{~g}$ for $5 \mathrm{~min}$ to pellet debris.

10. Retrieve and transfer the supernatant to a fresh tube. Add $1 / 0$ volume of $10 \times$ BN-PAGE loading buffer to each sample.

Do NOT heat the samples, as this will denature the proteins and their complexes and defeats the object of $B N-P A G E$. As complexes will potentially disassociate on storage, only prepare as much sample as will be run on the day of the experiment.

11. Proceed to BN-PAGE as described by Wittig et al. (2006) followed by immunoblotting.

i. Assemble the native gels in the gel tank. Add anode buffer to the outer chamber of the tank so that it reaches halfway up the gel. Before loading the samples, add sufficient cathode buffer I to fill the "wells only," rather than the whole inner chamber.

This allows you to see the samples as they are loaded and helps prevent displacement of the sample when the tank is finally filled with cathode buffer $I$.

ii. Load samples alongside native markers.

Load samples as sufficient to detect Bak/Bax by immunoblotting. This will vary depending on cell type and should be established empirically. It is important not to "overload" the gel, as this will reduce the definition of the complexes.

iii. Run gels according to Table 1. After the Coomassie dye front has migrated a one-third of the way through the separation gel, replace cathode buffer I with cathode buffer II to allow protein visualization and aid subsequent transfer. Run the gel until the Coomassie dye front nears the bottom of the gel

Abundant mitochondrial respiratory complexes can be directly visualized postelectrophoresis.

iv. Before transfer, equilibrate the gel in Tris-glycine/MeOH transfer buffer supplemented with $0.037 \%$ SDS.

v. Transfer to PVDF membrane as normal. After transfer, stain the blot with Coomassie stain. Destain in 50\% methanol $/ 25 \%$ acetic acid to more easily visualize the markers.

Coomassie staining and destaining is only compatible with PVDF and not nitrocellulose membranes.

vi. If necessary, incubate the blot for $30 \mathrm{~min}$ at $65^{\circ} \mathrm{C}$ in Tris-glycine buffer with SDS/BME to denature proteins and aid immunodetection.

See Troubleshooting.

TABLE 1. Gel-running conditions for BN-PAGE

\begin{tabular}{lll}
\hline & Electrophoresis (at room temperature) & Transfer \\
\hline Large gel $(12 \mathrm{~cm} \times 15 \mathrm{~cm})$ & $7 \mathrm{~mA}$ until Coomassie dye enters & $400 \mathrm{~mA}$ for $2 \mathrm{~h}$ \\
Mini gel & $8 \mathrm{~mA}$ for $\sim 1.5 \mathrm{~h}$ & $30 \mathrm{~V}$ for $2.5 \mathrm{~h}$
\end{tabular}


G. Dewson

TROUBLESHOOTING

Problem (Step 11): Proteins cannot be detected following immunoblotting.

Solution: The success of BN-PAGE is dependent on recognition of the native conformer of the protein of interest by the immunoblotting antibody, and so a number of antibodies should be tested. In addition, this limitation can be overcome by incubating the immunoblot with SDS and $\beta$-mercaptoethanol in Tris-glycine buffer for $30 \mathrm{~min}$ at $65^{\circ} \mathrm{C}$ to effectively denature the proteins and reveal occluded epitopes (Valentijn et al. 2008).

\section{DISCUSSION}

Bak and Bax oligomers form in the mitochondrial outer membrane (MOM) and thus can be monitored by BN-PAGE (Valentijn et al. 2008; Lazarou et al. 2010; Dewson et al. 2012). In our experience, Bak and Bax apoptotic oligomers are stable following solubilization from the MOM in 1\% digitonin and subsequent BN-PAGE. It is important to note that the redox conditions within a cell vary depending on the subcellular compartment. The need for the addition of a reducing agent during the sample preparation will depend on the native environment of the complexes under investigation. For example, if the complex is exposed to the reducing environment of the cytosol, as with Bak and Bax, then addition of DTT is recommended to prevent artifactual disulphide-bonding during membrane solubilization that will alter the complexes detected on BN-PAGE. If required, DTT should be added at a concentration of 2-10 mM "throughout" sample preparation (Steps 3-8).

BN-PAGE Loading Buffer (10x)

5\% (w/v) Coomassie blue G-250

$500 \mathrm{~mm}$ aminocaproic acid

Cathode Buffer I (10x)

$500 \mathrm{~mm}$ Tricine

$75 \mathrm{~mm}$ imidazole, $\mathrm{pH} 7$

$0.2 \%(\mathrm{w} / \mathrm{v})$ Coomassie blue G-250

Store at $4^{\circ} \mathrm{C}$.

Cathode Buffer II (10x)

500 mm Tricine

$75 \mathrm{~mm}$ imidazole, $\mathrm{pH} 7$

Store at $4^{\circ} \mathrm{C}$.

Coomassie Stain

$50 \%$ methanol

$10 \%$ acetic acid

0.25\% (w/v) Coomassie blue R-250

\section{Permeabilization Buffer}

20 mм HEPES/KOH, pH 7.5

$250 \mathrm{~mm}$ sucrose

$50 \mathrm{~mm} \mathrm{KCl}$

$2.5 \mathrm{~mm} \mathrm{MgCl}_{2}$ 
Phosphate-Buffered Saline (PBS)

\begin{tabular}{|c|c|c|c|c|}
\hline Reagent & $\begin{array}{l}\text { Amount to add } \\
\text { (for } 1 \times \text { solution) }\end{array}$ & $\begin{array}{c}\text { Final } \\
\text { concentration } \\
(1 \times)\end{array}$ & $\begin{array}{l}\text { Amount to add } \\
\text { (for } 10 \times \text { stock) }\end{array}$ & $\begin{array}{c}\text { Final } \\
\text { concentration } \\
(10 \times)\end{array}$ \\
\hline $\mathrm{NaCl}$ & $8 \mathrm{~g}$ & $137 \mathrm{~mm}$ & $80 \mathrm{~g}$ & $1.37 \mathrm{M}$ \\
\hline $\mathrm{KCl}$ & $0.2 \mathrm{~g}$ & $2.7 \mathrm{~mm}$ & $2 \mathrm{~g}$ & $27 \mathrm{~mm}$ \\
\hline $\mathrm{Na}_{2} \mathrm{HPO}_{4}$ & $1.44 \mathrm{~g}$ & $10 \mathrm{~mm}$ & $14.4 \mathrm{~g}$ & $100 \mathrm{~mm}$ \\
\hline $\mathrm{KH}_{2} \mathrm{PO}_{4}$ & $0.24 \mathrm{~g}$ & $1.8 \mathrm{~mm}$ & $2.4 \mathrm{~g}$ & $18 \mathrm{~mm}$ \\
\hline \multicolumn{5}{|c|}{ If necessary, PBS may be supplemented with the following: } \\
\hline $\mathrm{CaCl}_{2} \cdot 2 \mathrm{H}_{2} \mathrm{O}$ & $0.133 \mathrm{~g}$ & $1 \mathrm{~mm}$ & $1.33 \mathrm{~g}$ & $10 \mathrm{~mm}$ \\
\hline $\mathrm{MgCl}_{2} \cdot 6 \mathrm{H}_{2} \mathrm{O}$ & $0.10 \mathrm{~g}$ & $0.5 \mathrm{~mm}$ & $1.0 \mathrm{~g}$ & $5 \mathrm{~mm}$ \\
\hline
\end{tabular}

PBS can be made as a $1 \times$ solution or as a $10 \times$ stock. To prepare $1 \mathrm{~L}$ of either $1 \times$ or $10 \times \mathrm{PBS}$, dissolve the reagents listed above in $800 \mathrm{~mL}$ of $\mathrm{H}_{2} \mathrm{O}$. Adjust the $\mathrm{pH}$ to 7.4 (or 7.2, if required) with $\mathrm{HCl}$, and then add $\mathrm{H}_{2} \mathrm{O}$ to $1 \mathrm{~L}$. Dispense the solution into aliquots and sterilize them by autoclaving for $20 \mathrm{~min}$ at 15 psi $\left(1.05 \mathrm{~kg} / \mathrm{cm}^{2}\right)$ on liquid cycle or by filter sterilization. Store PBS at room temperature.

Solubilization Buffer

$50 \mathrm{~mm} \mathrm{NaCl}$

$5 \mathrm{~mm}$ aminocaproic acid

1 mM EDTA

$50 \mathrm{~mm}$ imidazole/ $\mathrm{HCl}, \mathrm{pH} 7$

$1 \%$ digitonin

Tris-Glycine Buffer with SDS/BME

$25 \mathrm{~mm}$ Tris

$192 \mathrm{~mm}$ glycine

$5 \%$ sodium dodecyl sulfate

2\% $\beta$-mercaptoethanol

Tris-Glycine/MeOH Transfer Buffer

$25 \mathrm{~mm}$ Tris

192 mm glycine

20\% (v/v) methanol

\section{ACKNOWLEDGMENTS}

G.D. is supported by the National Health and Medical Research Council of Australia (637335), Australian Research Council (FT100100791), and the Association for International Cancer Research (10-230). The present work was made possible through Victorian State Government Operational Infrastructure Support and Australian Government NHMRC IRIISS.

\section{REFERENCES}

Dewson G, Ma S, Frederick P, Hockings C, Tan I, Kratina T, Kluck RM. 2012. Bax dimerizes via a symmetric BH3:groove interface during apoptosis. Cell Death Differ 19: 661-670.

Lazarou M, Stojanovski D, Frazier AE, Kotevski A, Dewson G, Craigen WJ, Kluck RM, Vaux DL, Ryan MT. 2010. Inhibition of Bak activation by VDAC2 is dependent on the Bak transmembrane anchor. J Biol Chem 285: $36876-36883$.
Valentijn AJ, Upton JP, Gilmore AP. 2008. Analysis of endogenous Bax complexes during apoptosis using blue native PAGE: Implications for Bax activation and oligomerization. Biochem J 412: 347-357.

Wittig I, Braun HP, Schagger H. 2006. Blue native PAGE. Nat Protoc 1: 418-428. 


\section{Blue Native PAGE and Antibody Gel Shift to Assess Bak and Bax Conformation Change and Oligomerization}

Grant Dewson

Cold Spring Harb Protoc; doi: 10.1101/pdb.prot086488

\begin{tabular}{|c|c|}
\hline $\begin{array}{l}\text { Email Alerting } \\
\text { Service }\end{array}$ & Receive free email alerts when new articles cite this article - click here. \\
\hline $\begin{array}{l}\text { Subject } \\
\text { Categories }\end{array}$ & $\begin{array}{l}\text { Browse articles on similar topics from Cold Spring Harbor Protocols. } \\
\text { Cell Biology, general (1382 articles) } \\
\text { Characterization of Protein Complexes ( } 83 \text { articles) } \\
\text { Characterization of Proteins ( } 208 \text { articles) } \\
\text { Electrophoresis ( } 57 \text { articles) } \\
\text { Electrophoresis of Proteins ( } 97 \text { articles) } \\
\text { Protein Expression and Interactions (93 articles) } \\
\text { Subcellular Fractionation ( } 88 \text { articles) }\end{array}$ \\
\hline
\end{tabular}

